\title{
Free Kappa Light Chain Measurement
}

National Cancer Institute

\section{Source}

National Cancer Institute. Free Kappa Light Chain Measurement. NCI Thesaurus. Code C98730.

The determination of the amount of free kappa light chain present in a sample. 